\title{
A Review on Electric Vehicle Charging Systems and Current Status in Turkey
}

\author{
Yunus Emre Ekici ${ }^{1}$, İsmail Can Dikmen ${ }^{1}$, Mustafa Nurmuhammed ${ }^{1}$ and Teoman Karadağ $\breve{2}^{2 *}$ \\ 0000-0001-7791-0473, 0000-0002-7747-7777, 0000-0002-5957-3255, 0000-0002-7682-7771 \\ ${ }^{I}$ Electric and Hybrid Vehicle Technologies Department, OSB Vocational School, Inonu University, Malatya, 44000, Turkey \\ ${ }^{2}$ Electric Electronics Engineering Department, Inonu University, Malatya, 44000, Turkey
}

\section{Abstract}

The reality of global warming brings along an increase in environmental awareness. In recent years, this awareness has shifted public focus on electric vehicles. For a large group of people greenhouse gas emission is attributed to internal combustion engines. However, some challenges have arisen for electric vehicles. Limited range due to immature battery technologies and insufficient fast charging technologies that do not meet end user expectations are some major obstacles to overcome. Eventually this situation negatively affects the sales and the wide use of electric vehicles. That is the reason why studies on wired and wireless charging systems play an important role in improving the sales performance of electric vehicles. In this study a thorough review of worldwide electric vehicle charging systems is conducted and discussed in the framework of the electric vehicles, charging stations, installations, and implementation of standards in Turkey. The distribution of charging stations in Turkey are analyzed with respect to location, region, type, infrastructure requirements and future projections. The historical development of charging technologies, modes and charge levels have been studied in detail. As highlight of this study, wireless charging technologies were also discussed and the historical development process was analyzed along with related standards. The current state of electric vehicle sector and charging stations in Turkey are discussed and provided with up to date information.

Keywords: Dynamic charging; electric vehicle (EV); inductive power transfer (IPT); wireless power transfer (WPT)
Review Article

https://doi.org/10.30939/ijastech..958368

$\begin{array}{ll}\text { Received } & 27.06 .2021 \\ \text { Revised } & 06.08 .2021 \\ \text { Accepted } & 10.09 .2021\end{array}$

* Corresponding author

Teoman Karadağ

teoman.karadag@inonu.edu.tr

Address: Electric Electronics Engineering Department, Faculty of Engineering, Inonu University, Malatya, Turkey

Tel: +905434455544

\section{Introduction}

The electric vehicle technology, whose scientific and technical infrastructure emerged in the 19th century, has continued to develop intermittently since then. Until the 20th century, numerous electric vehicles were designed, manufactured and sold commercially. In fact, in 1885 an electric car made by Immisch Electric Works company in London which is produced for His Imperial Majesty the Sultan of Turkey, Abdul Hamid II $(1,2)$. Due to the unabated relevance on electric vehicles approximately 4200 cars hit the roads until 1918. Later, with the falling oil prices and the development of the alternator, internal combustion engine technology regained its dominance. Nevertheless, some automotive manufacturers have continued their vehicle production adventure with different energy storage systems and drive motors (3).

During the $21^{\text {st }}$ century, progress in the electric vehicles industry has gained great momentum. The first ever mass produced electric car was General motors EV1 with limited technical capabilities. The EV1 had a fairly reasonable range reaching up to 169 $\mathrm{km}$ (105 miles) which depends on its battery chemistry which is lead-acid or Nickel Metal Hydride (NiMH). Due to limited selling zone mainly in cities of Los Angeles, California, Phoenix and Tucson, Arizona only 1,117 units were produced (4).With the introduction of long-range vehicles by various companies, interest and investment in this technology have started to increase again. In this trend, Tesla Motors was established in California in 2003. In 2004, Tesla Motors began working on the Tesla Roadster, a $100 \%$ electric sports car based on the popular and stylish Lotus Elise design.

In 2006, Tesla Roadster was exhibited at the San Francisco International Auto Show. The Tesla Roadster has inspired the design of many electric cars to come, influenced their appearance, and encouraged some major automakers to transition into electric car industry. In 2008, the Tesla Roadster was the first mass-produced electric car to use lithium-ion battery cells, as well as the 
first mass-produced electric vehicle to have a range of over 200 miles (approximately $320 \mathrm{~km}$ ) on a single charge (5). In the same year while campaigning for the presidency, Barack Obama stated that when he was elected president, by 2015 there would be 1 million plug-in hybrid and fully electric vehicles on the US roads (6). By 2019, approximately 7.2 million electric cars were on the roads worldwide increasing daily (7).

The transportation is the primary industry that contributes to $\mathrm{CO}_{2}$ emissions and thus to climate change $(8,9)$. Fossil fuels used by internal combustion engines release gases that adversely affect the environment. As a result, the adoption of more environmentally friendly transportation technologies has become a necessity in today's world, where environmental awareness has increased (10). Therefore, the development of transportation technologies based on alternative fuels is of great importance (11). World countries aim to prevent $\mathrm{CO}_{2}$ emissions by implementing environmental policies (12). Therefore, development of electric vehicle technology is very imperative (13). Undoubtedly, electric transportation has deeply affected the transportation industry. Consequently, it has accelerated the adoption of electric vehicles and increased the production $(14,15)$.

Between 2007 and 2010, a total of 11,768 fully electric vehicles were produced (16). However, as of 2013, a total of 206,000 electric cars, mostly plug-in hybrid models, were sold in 2013 alone (17). The target of producing 1.9 million fully electric vehicles for 2017 was achieved by the end of that year (18). In 2019, a total of 3 million electric vehicles were sold (18). Electric vehicles use electric drivetrain as a means of moving force. The energy needed by the electric motors is provided by the batteries on the vehicle.

Electric vehicles, like many other technologies, started to be developed in the laboratory environment and gained their place in our daily life with the help of industrialization. Various hardware and software are used in conjunction in the implementation of electric vehicle technology. These equipment such as battery group, electric motor, and inverter can be located on-board or outside the vehicle. The best example of this is the charger used to charge the vehicle's batteries.

In order to maintain the mobility of electric vehicles, the batteries must be charged. The charger provides charging by converting the voltage received from the grid to the required form in order to store energy in the batteries (19).

The steps to do this charging process are as follows (20):

1. Start of charging

2. Balancing when charging is near complete

3. Stop charging

In addition, three different methods can be used while charging the batteries. The first of these can be done by wire, the second by wireless, ie by electromagnetic transmission without any contact and the third is by swapping the battery (21). It is stated in the literature that the charging process of the battery group connected to the charging station is carried out by three different methods. These are the fixed frequency method, the alternating current method from the network and the charging method with direct current through a rectifier. In this article, wired and wireless charging methods are discussed in detail $(22,23)$.

\section{Wired Charging Systems}

Wired charging is a charging method that provides direct transmission of electricity supplied from a generator to the charging connector on the vehicle with a conductive cable terminated with a standard connector. Wired charging is used in fully electric or plug-in hybrid electric vehicles. It is essentially applied in two different ways: the first is charging at charging stations (homes or public places), and the second is swapping the battery with a fully charged one. Charge types are divided into two as AC charging and DC fast charging.

\subsection{AC regular charging}

In the wired charging method, a conductor and a connector are needed for charging operation. The cable transfers the required energy from a standard power socket or a public charging station to the electric vehicle. The biggest disadvantage of this method is that the user plugs the cable and the socket. Any fault or lack of contact in the cable can lead to undesirable results (14).

CHAdeMO charging standard is used in Japan. In the rest of the world, SAE is set as the AC charging standard $(24,25)$. However, there is no official standard yet for the DC charging system. Countries use their own DC charging standards. Wired charging needs to be done according to certain procedures. For this, charging is performed with three different charge levels as standard. In fact, it can be said that the charge levels basically describe the power levels.

\section{Level 1 Charging System}

Level 1 charge is the charge made with the charging socket and charging cable in the vehicle. Required power is obtained from a commonly grounded socket (NEMA 5-15R). The initial cost for this charging method (wiring for energy infrastructure, operation maintenance and repair) is approximately 800 dollars (26). Level 1 charging configuration according to SAE standards is shown in Fig. 1 (27).

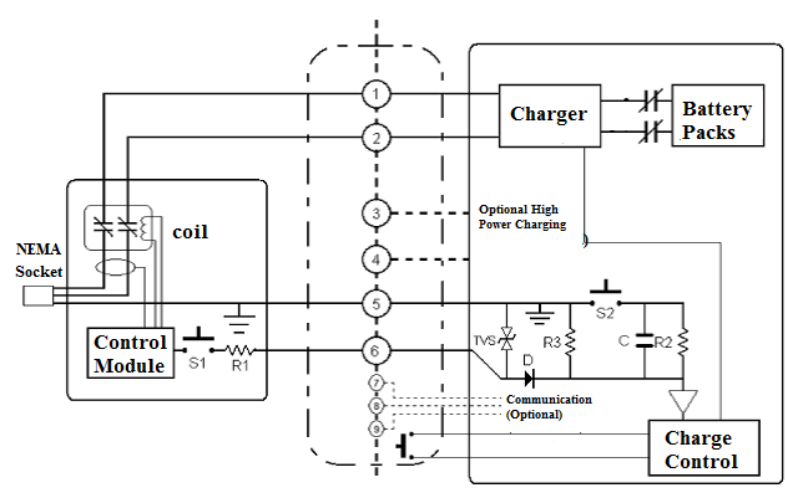

Fig. 1. Level 1 AC charge configuration (28) 


\section{Level 2 Charging System}

Level 2 charging is generally used at private or public charging stations. The charging connector, cables and $\mathrm{AC}$ charging infrastructure are used. This charging method is called "Fast AC charging" at $7 \mathrm{~kW}$ (32 Amps single phase) or $21 \mathrm{~kW}$ (three phase). The Level 2 charging method also applies to workplaces or public charging stations. The initial cost for this charging method (wiring for energy infrastructure, operation maintenance and repair) is approximately 3,000 dollars (29). Fig. 2 shows the Level 2 charging configuration according to SAE standards (28).

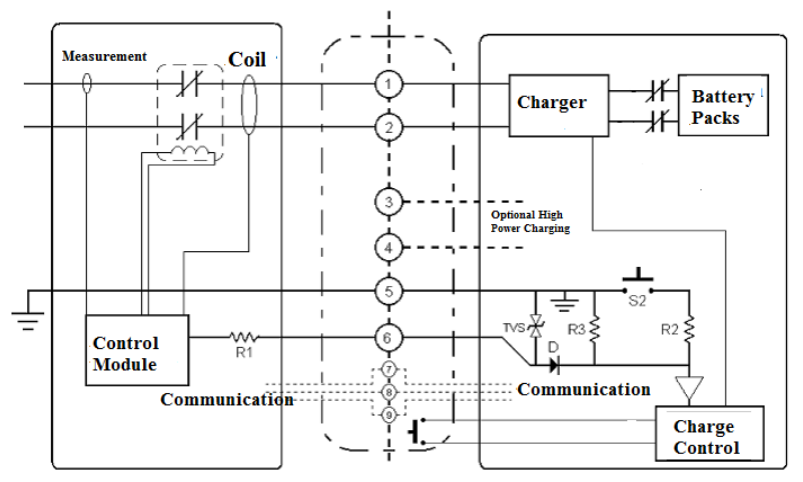

Fig. 2. Level 2 AC charge configuration (28)

\section{Level 3 Charging System}

In this charging method, batteries are charged with direct current at public or private charging stations. While charging is taking place, there must be a suitable conductor and suitable connector. DC charging is much faster than AC Level 1 and Level 2 charging. Level 3 charging system can also be considered as fast DC charging and depending on the vehicle $50 \mathrm{~kW}$ of power can easily be directed to the vehicle (30). With Level 3 charger battery can be charged from $0 \%$ to $80 \%$ in just around 20 minutes (31). In addition, the initial cost of such a power system (including infrastructure, operation, etc.) is between 40,000 and 70,000 dollars (26). The charge configuration for Level 3 is shown in Fig. 3 (32).

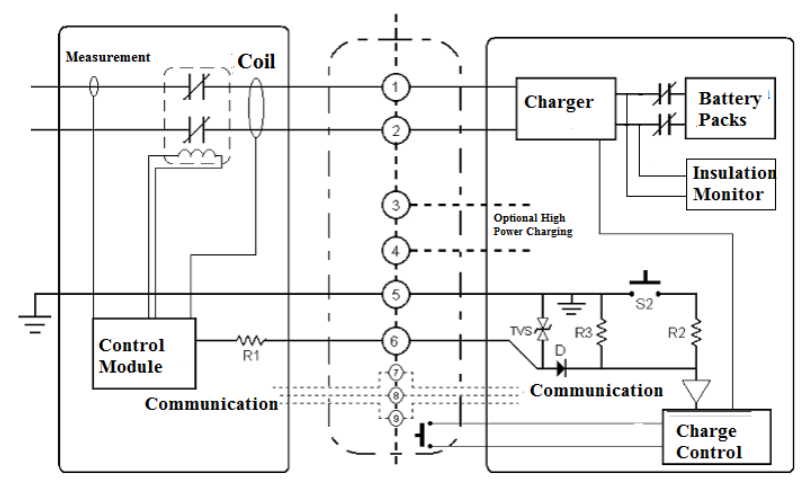

\subsection{DC fast charging}

In 2012, approximately 2400 DC charging stations were sold around the world. In 2019, this number is increased to 100,000. According to Pike Research, this figure is estimated to reach 460,000 in 2020 (33). While DC fast chargers provide users with faster charging possibilities, they have the potential to impose a sudden load on the electricity grid due to the high power demand of the charging station and thus to incur significant costs. For this reason, DC fast charging stations can cost several thousand dollars more annually for maintenance, repair and service (34). Therefore, installing charging stations in public areas at optimum locations may help reducing possible annual extra costs (33). One of the most important reasons for the widespread of electric cars is the expansion and development of charging infrastructure (35). The power of a charging station is usually an optimization calculation between infrastructure investment and the length of charging time (29). The charging infrastructure is divided into two as AC and DC charging shown in detail in Table $1(36,37)$. In addition, there are three main organizations, IEC, CHAdeMO and SAE, in the world working on standardizing the electric car charging process and provide legal infrastructure. Tesla uses its own proprietary charging standard.

Table 1. Electric vehicle charging standards and power ratings $(38,39)$

\begin{tabular}{|c|c|c|}
\hline Level & $\begin{array}{l}\text { Maximum } \\
\text { Power }(\mathrm{kW})\end{array}$ & $\begin{array}{c}\text { Maximum } \\
\text { Current (A) }\end{array}$ \\
\hline \multicolumn{3}{|c|}{ IEC } \\
\hline \multicolumn{3}{|c|}{ AC Charge } \\
\hline AC Level 1 & $4-7,5$ & 16 \\
\hline AC Level 2 & $8-15$ & 32 \\
\hline AC Level 3 & $6-120$ & 250 \\
\hline DC Charge & $100-200$ & 400 \\
\hline \multicolumn{3}{|c|}{ SAE } \\
\hline \multicolumn{3}{|c|}{ AC Charge } \\
\hline AC Level 1 & 2 & 16 \\
\hline AC Level 2 & 20 & 80 \\
\hline AC Level 3 & $>20$ & - \\
\hline \multicolumn{3}{|c|}{ DC Charge } \\
\hline DC Level 1 & 40 & 80 \\
\hline DC Level 2 & 90 & 200 \\
\hline DC Level 3 & 240 & 400 \\
\hline \multicolumn{3}{|c|}{ CHAdeMO } \\
\hline DC Fast Charge & 62,5 & 125 \\
\hline
\end{tabular}

Fig. 3. Level 3 DC charge configuration (28) 
Charging duration of electric vehicles depends on three main factors (39). The size of the battery pack, the power rating of the charger and the number of electric vehicles currently connected to the charger (40). Level 1 and Level 2 charging processes generally take longer and as the size of battery packs and the number of electric vehicles increase, these charging stations become insufficient.

Therefore, the DC fast charger stands out as the most promising candidate to meet this requirement. DC fast charging is essential for EV users, as well as for commercial charging networks. DC fast charging is offered by IEC CHAdeMO, SAE J1772 Combo and Tesla Supercharger. Comparison of various DC fast charger connectors and standards can be found in Table 2 .

Today, the controller area network (CAN) and PLC protocols are used to establish secure communication between the electric vehicle power management system and the charger control units.

\subsection{Charging Modes}

According to the widely used international charging standard IEC 62196, four different charging modes that define the general characteristics of various charging types for both electric vehicles and charging equipment are determined. These are the de facto standards in the electric vehicle industry and each manufacturer is obliged to produce charging stations that comply with these standards. Charging modes determined according to the IEC 62196 standard are presented in Table 3.

Table 2. Charging modes.

\begin{tabular}{c|c|c|c}
\hline Mode & $\begin{array}{c}\text { Proprietary } \\
\text { Socket }\end{array}$ & $\begin{array}{c}\text { Control, communication } \\
\text { and protection system }\end{array}$ & AC/DC \\
\hline 1 & No & No & AC \\
\hline 2 & No & Yes & AC \\
\hline 3 & Yes & Yes & AC \\
\hline 4 & Yes & Yes & DC \\
\hline
\end{tabular}

\section{Mode 1 Charging}

This charging mode is generally used in home environment (42). Charging is carried out using a standard power socket. Since this charging process can be relatively dangerous, it is not legally appropriate in many countries (23).

Table 3. List of major inlets and connectors (41)

\begin{tabular}{|c|c|c|c|c|c|c|}
\hline & CHAdeMO & GB/T & $\begin{array}{c}\text { US- } \\
\text { COMBO } \\
\text { CCS1 }\end{array}$ & $\begin{array}{c}\text { EURO- } \\
\text { COMBO CCS2 }\end{array}$ & TESLA & Chaoji \\
\hline \multicolumn{7}{|l|}{ Connector } \\
\hline \multicolumn{7}{|l|}{ Inlet } \\
\hline Market Power & $150 \mathrm{~kW}$ & $125 \mathrm{~kW}$ & $150 \mathrm{~kW}$ & $350 \mathrm{~kW}$ & $120 \mathrm{~kW}$ & - \\
\hline Connectors & 27,500 & 300,000 & 3,000 & 11,000 & 20,000 & - \\
\hline Starts & 2009 & 2013 & 2014 & 2013 & 2012 & 2020 Target \\
\hline
\end{tabular}

It can be applied as 250 Volts single phase or 480 Volts three phase, not exceeding 16 amps. When using this charging system, protective elements such as fuses and relays are used to protect against adverse situations such as high voltage and short circuit $(43,44)$ In Fig. 5, the visual of Mode 1 charging process is presented. In Mode 1 charging, it is very important that the energized point has a proper ground. In addition, integrating overcurrent or overvoltage protective systems is another requirement. Furthermore, connectors must be protected from accidentally touching each other. 

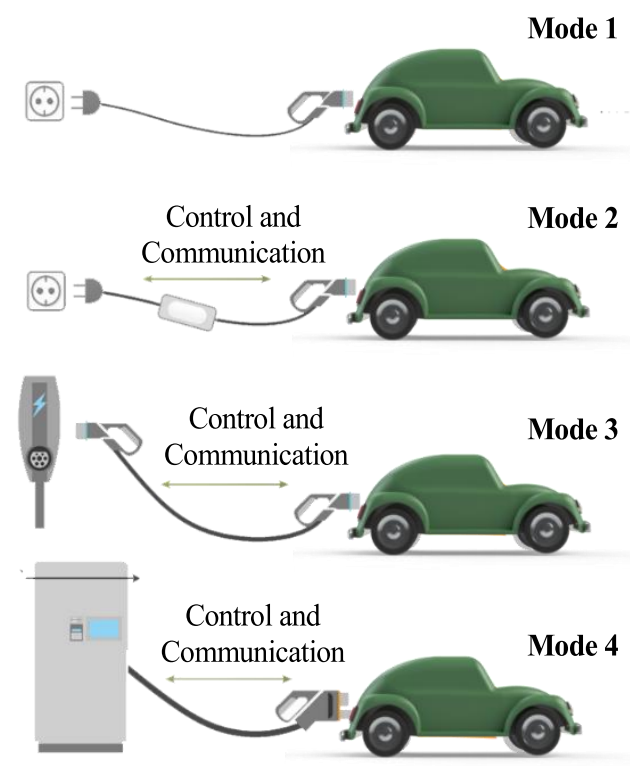

Fig. 4. Charging modes (45)

\section{Mode 2 Charging}

Mode 2 charging is also used in the home environment. The required power is supplied from the house and is carried out via the charger installed by the manufacturer. Household feeding equipment and the cable supplied by the manufacturer are used during this process. The manufacturer is obliged to provide safety layers for charging supply equipment, including overcurrent, overvoltage, and temperature protection and earth leakage detection systems.

The charging process starts when the wall charging station is detected. In order to do this, communication between the vehicle and the home charging station must be established. There is no regulation for home charging stations, but it must meet the minimum standards. For Mode 2 charging, shown in Fig. 4, a 250 volts single phase or a 480 volts three-phase system can be used. The maximum current drawn from the network is 32 amperes (46).

\section{Mode 3 Charging}

Special infrastructures are used in Mode 3 charging method. Energy is taken from integrated systems with permanent control and protection functions with connector [50]. It is a charging method that complies with all standards that control and regulate electrical infrastructures. In Mode 3 charging method, energy can be transferred from the charging station to the vehicle and from the vehicle to the charging station. With the V2C (Vehicle to Charger) power transfer, the required energy from the vehicle can be transferred to other vehicles via the charging station. With V2V (Vehicle to Vehicle) power transfer, electric vehicles can transmit their energy over a local network via bidirectional chargers and then distribute the energy between electric vehicles. Therefore, V2V allows a flexible power transfer between electric vehicles. The Mode 3 charging method has the same safety standards of Mode 2, and charging takes place in public areas. The Mode 3 charging method presented in Fig. 4 can provide more power from the charger to the vehicle than Mode 2 during charging. Charging stations using this method are constantly connected to the energy infrastructure system and the systems are controlled by special control methods (47).

\section{Mode 4 Charging}

In this charging method, the infrastructure and socket installations are intended to be permanent. Direct current (DC) is used in this charging process, which can take place in public, at home or in public charging stations. Nowadays, DC charging comes standard for most electric vehicles but some manufacturers keep it optional. For DC charging to happen, vehicle should have a DC charging inlet (CCS, CHAdeMO etc.) and the charging station should have DC charging feature. The DC charging station converts the alternating current it receives from the power grid to direct current and enables the vehicle to charge in DC. Mode 4 charging is shown in Fig. 4.

\section{Charging Connectors}

The part that provides the vehicle and charging station connection is called the charging connector or socket. The type of charging connector depends on the vehicle and power rating of charging inlet (48). The charging connector for electric vehicles often varies according to standards and geography (49). At the same time, charging power is among the effective parameters. Charging standards include the Combined Charging System (CCS), the Chinese and CHAdeMO standards. Charging sockets with different forms are presented in Fig. 5.

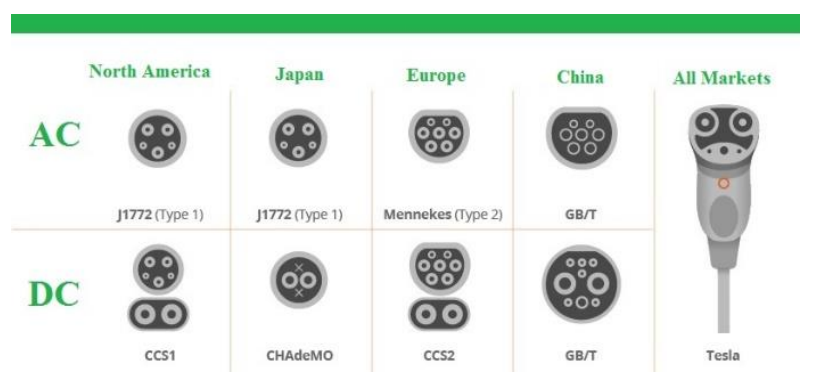

Fig. 5. Charging socket types according to different standards (50)

\section{North American AC Charging Connector Standard}

SAE J1772 connector, also known as the J-plug, is used for North American standard Level 1 and Level 2 charging. This standard does not apply for Tesla but Tesla vehicles can be connected to these charging stations with an adapter connector (50).

\section{North American DC Fast Charging Connector Standard}

The DC fast charging standard is generally used in public places and long distance travels. Since AC to DC conversion is done externally, a controlled infrastructure must be established. DC fast charging stations can be installed in the home environment; however, they are generally installed in public areas due to high cost. In addition, the use of DC fast charging once or twice a week is 
recommended by experts. With DC fast charging, the technical charging limit values of batteries are forced to the fullest. This is a form of charging that is not very suitable for battery chemistries. For DC fast charging, voltage range is $50-1000 \mathrm{~V}(51)$. The vehicle is charged in a short time. Three different types of connectors are used for DC fast charging (52). DC charging methods can be found on Table 4.

Table 4. SAE defined electrical ratings for DC charging are specified as follows (51):

\begin{tabular}{c|c|c|c}
\hline Charge Method & $\begin{array}{c}\text { EVSE DC Out- } \\
\text { put Voltage (V) }\end{array}$ & $\begin{array}{c}\text { Max.Current } \\
(\mathrm{A})\end{array}$ & $\begin{array}{c}\text { Max Power } \\
(\mathrm{kW})\end{array}$ \\
\hline DC Level 1 & 50 to 1000 & 80 & 80 \\
\hline DC Level 2 & 50 to 1000 & 400 & 400 \\
\hline
\end{tabular}

\section{CCS (Combined Charging System)}

There are two more pins at the bottom of this charging connector, which is used in accordance with $\mathrm{J} 1772$ standards. This connector has been approved by the SAE and recognized for North America. There are numerous companies that use this charging connector for electric vehicles that they manufacture. They are: Audi, Porsche, Honda, Kia, Fiat, Hyundai, Volvo, Smart, MINI, General Motors, Ford, Chrysler, Dodge, Jeep, BMW, Mercedes, Volkswagen, Jaguar Land Rover, Bentley, Rolls Royce, and other vehicle manufacturers. Even though Tesla has its own proprietary connector, one of their vehicles, Model 3 for European countries, comes with CCS inlet while for other models Tesla is offering CCS adapter. CCS connector is presented in Fig. 5.

\section{CHAdeMO}

This socket, which has become a standard in Japan, is used wherever DC fast charging is available. Mitsubishi and Nissan (53) are among companies that use this connector. The CHAdeMO system is not compatible with the pins of the $\mathrm{J} 1772$ charging connectors. Therefore, it is necessary to use an adapter in order to start charging. The image of the CHAdeMO charging connector is presented in Fig. 6.

\section{Tesla}

Tesla has a proprietary charging standard with a network called Supercharger. It uses the same connector for Level 1 and Level 2 charging. When Tesla vehicles are in the Supercharger charging station, automatic identification system is applied. If the vehicle is not recognized, the charging process cannot be started (54). Tesla charging socket is shown in Fig. 5.

\section{European Connector Standards}

$230 \mathrm{~V}$ is used as charging voltage in Europe. Therefore, this charging connector is similar to the charging connector used in North America, except that it has half the voltage. For this reason, a Level 1 charger cannot be used in Europe. In general, IEC 62196 Type 2 standard is used in Europe (55). The DC fast charging socket used in Europe is the same as the one in North America. This way, electric vehicles in Europe are operated according to J1772 standards during the charging process. In Fig. 5, Mennekes charging connector in accordance with European standards is shown.

\section{Wireless Charging Systems}

The foundations of Wireless Power Transfer (WPT) technology date back to two hundred years ago. Nikola Tesla sadece 65 $(56,57)$, whose studies concentrated on magnetic fields, started to work on the wireless transmission of power in his laboratory in the city of Colorado Springs in 1899 (58,59). In 1961, a low electric current energy system was proposed by John Schuder (60). In 1964, the feasibility of wireless transmission of power to an airplane was confirmed by the microwave power transmission method by William Brown (61). In 1968, a solar powered satellite system was proposed by Peter Glaser on microwave power transmission (62).

By 2007, 60 watts of power was transmitted wirelessly to a distance of up to 2 meters by MIT (63). Wireless power transfer can be done in three different ways: electromagnetic radiation, electrical connection and magnetic connection $(64,65)$. Electromagnetic radiation method is used for long distance power transmission using microwaves. Although this mode is an inefficient method, it can be unsafe due to the radiation. The other two methods are less harmful and more suited for close distances. The electrical connection is also known as capacitive power conduction and the required energy is transmitted between the metal plate electrodes via an electric field. This mode is less researched than other modes in the literature. The reason for this is that the effect of electric field is more harmful for living beings than the magnetic field (66-70). Generally, the main components of the wireless charging system for electric vehicles are presented in Fig. 6.

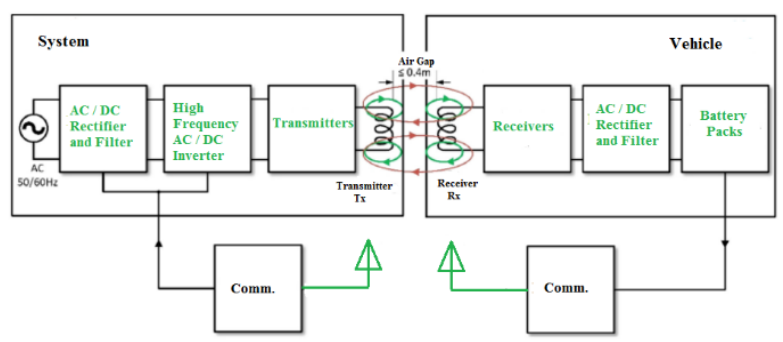

Fig. 6. Wireless charging system main components for electric vehicles (71)

The increase in the transportation industry worldwide has led to an increase in the greenhouse gas effect (72). Electric vehicle industry has gained more importance with this increase and thus the environmental awareness (73). Unlike vehicles with internal combustion engine, electric vehicles can benefit from renewable energy sources and have less greenhouse gas impact on the environment (74). However, with the short range and constantly developing battery technology, electric vehicles still face many problems. Wireless Power Transfer is seen as a promising solution to overcome some of these problems. WPT is safer and simpler than 
conventional chargers because it does not require a cable to transfer energy (75). Wireless power transfer can be accomplished in two different ways: dynamic charge and constant charge. In dynamic wireless charging, vehicles are in motion and in constant charging, vehicles are stationary. Dynamic charging can reduce the need for on-board battery capacity, increase the driving range, and thus reduce the weight and cost of the vehicle (76,77). In 2009, the dynamic charging system was developed by the Korea Advanced Science and Technology Institute in South Korea. To solve the power transmission distance problem, I-type coils and U-type power supply rails have been proposed. Power transfer was achieved within a distance of $17 \mathrm{~cm}$. However, there were efficiency issues. Only $72 \%$ efficiency and $60 \mathrm{~kW}$ power transfer have been obtained. As a result of this transfer, a promising technology was introduced in the charging of electric vehicles. Later, this technology was attempted to be tested on a road in South Korea. The test took place at a distance of $48 \mathrm{~km}$ and the efficiency rate was increased to $83 \%$ (76).

In 2010, Bombardier Company developed a charging system for trams. Because more power is required due to its weight, studies have been made for a higher charging power $(78,79)$. Since trams provide urban transportation, a power of $250 \mathrm{~kW}$ has been transferred by using both dynamic and fixed charging systems at the same time (80). In 2013, Oak Ridge National Laboratory in the USA started working on the circular coil and application research for electric vehicles (81). As a result of this study, a power of 2.2 $\mathrm{kW}$ was transferred with 74\% efficiency. In 2014, a fixed charging system with a distance of $20 \mathrm{~cm}$ was developed by the Chinese ZTE Corporation. This system could transfer $30 \mathrm{~kW}$ of power. Later, it is enhanced to an efficiency of $90 \%$ (82). Many researchers and companies have worked on wireless charging transfer. The research adventure, started in 1800s with Hertz and Tesla, continued in 2009 with the studies of KAIST University in Korea (83). In addition, company-level research started in 1996 with General Motors and continued with Nissan in 2017. Studies on wireless power transfer are presented in the form of milestone in Fig. 7 and Fig. 8. After 2017, companies such as WiTricity, Conductix-Wampfler, LG, Evatran, Momentum Dynamics and Qualcomm HaloIPT continued their studies on efficiency and cost analysis on the wireless charging system 96 (84). In this section, fixed wireless charging and dynamic wireless charging are examined in detail.

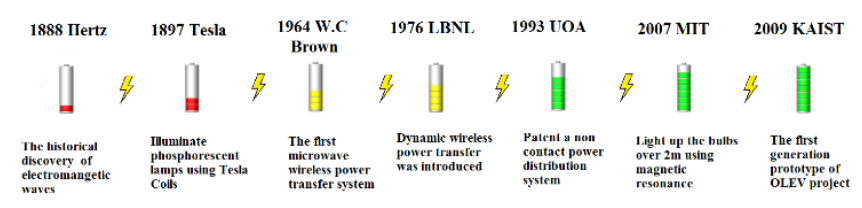

Fig. 7. Academic studies for wireless charging (85)

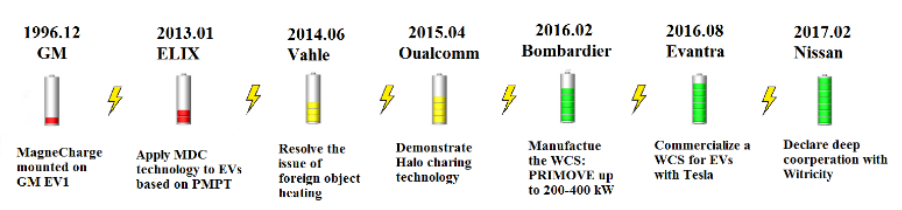

Fig. 8. Industrial studies on wireless charging (85)

\subsection{Static Wireless Charging System}

The fixed wireless charging method has been developed to provide safer environment for electric vehicle users. When the useroriented charging process of wired charging stations is carried out, dangers such as electric shock may be encountered during plugging and unplugging cable. A fixed wireless charging system is shown in Fig 9.

A coil is placed under the vehicle to transfer the required power. The receiver coil can be mounted at the front, rear or middle of the vehicle. The receiver converts the incoming AC power to DC and allows it to be stored in batteries. In order to avoid safety problems, the battery management system works actively during the charging process and oversees the system.

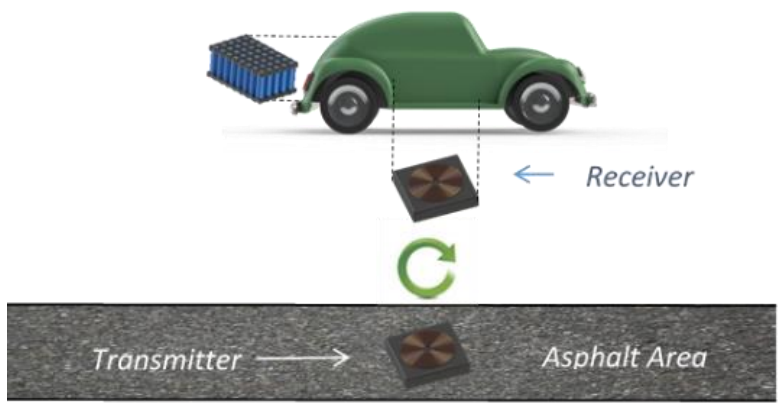

Fig. 9. Static wireless charging system

The charging time varies depending on the battery capacity and the distance of the air gap between the receiver and transmitter.

For passenger cars, this distance varies between 150-300 mm (86). Fixed wireless electric vehicle charging system can be installed in homes, parking lots, shopping malls and parking areas.

Researchers and commercial level organizations have conducted many researches on fixed wireless electric vehicle charging method as seen in Table $5(70,87-89)$. 
Research \& Development Institute / Company

Vehicle Type

Efficiency

$(\%)$

Plugless Power (Evatran Group) (2016-17)

Passenger Cars

90

WiTricy Corporation (2009-17)

Passenger Cars and SUV

$>90$

Qualcomm Halo (2010-17)

Passenger Cars, sport and race

$>90$

Hevo Power (2017-18)

Passenger Cars

90

Bombardier Primove (2015-17)

Passenger Cars and

$>85$

Momentum Dynamic Corporation (2015-17)

E-bus Commercial Fleet and Bus

TBA

Conductix-Wampfler (2002-03)

Industry Fleet- and Bus

TBA

Siemens and BMW

Passenger Cars

$>90$

Delphi (2011-17)

Passenger Cars

TBA

Wuhan University, China (2017)

Experimental

$\approx 81$

Korea Institute of Industrial Technology (KITECH) (2016)

Experimental

Michigan State University (2016)

Experimental

KAIST University (2016)

Experimental

95.96

Oak Ridge National Lab (ORNL) (2013-17)

Prototype

$\approx 89-90$

University of Michigan-Dearborn (2014)

Experimental

90

University of Auckland (1997-17)

Passenger Cars

$>85$

The University of Georgia (2014-17)

Prototype

$>80$

Energy Dynamics Laboratory (EDL)

Experimental

$>90$

and Utah State University (2012)

KAIST University (2010-14)

Passenger Cars and SUV

$74-83$

The calculated cost for charging power varying between 3.3-7.2 $\mathrm{kW}$ varies approximately between 2700-13.000 USD (91). It is possible to operate between $3.3 \mathrm{~kW}$ and $7.2 \mathrm{~kW}$ with frequency ranges of $81.9-90 \mathrm{kHz}$. Therefore, $3.3 \mathrm{~kW}$ was previously offered as a Level 1 charge and $7.2 \mathrm{~kW}$ as a Level 2 charge. This charging method has been developed in accordance with the SAE J2954 standard (92). Generally, laboratory studies have calculated the efficiency of a power transfer for $1 \mathrm{~kW}$ and $20 \mathrm{~kW}$ at a distance of $100-300 \mathrm{~mm}$ to be between $71 \%$ and $95 \%$ (93).

\subsection{Dynamic Wireless Charging System}

One of the biggest problem for plug-in electric, hybrid and fully electric vehicles is the weight of the battery depending on its energy capacity (37). It is very common to use high capacity batteries to eliminate the range issue. High capacity battery also means excessive battery cells and additional weight. This is undesired for automotive manufacturers. Dynamic wireless charging aims minimizing the cost by eliminating the need for a high capacity battery. This system is also known as road powered systems (81). The basic scheme of dynamic wireless charging system is presented in Fig. 10 and 11

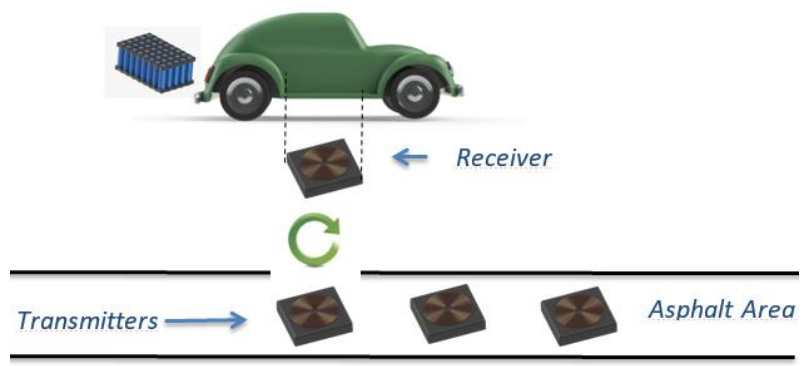

Fig. 10. Basic diagram of the dynamic wireless charging system $(94,95)$ 


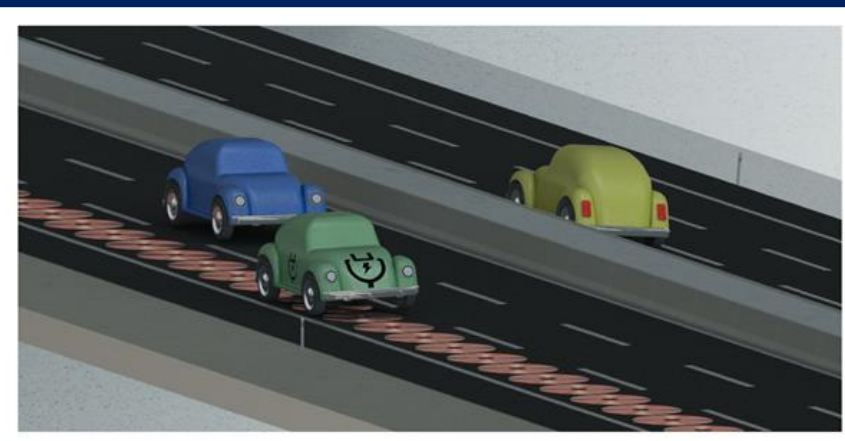

Fig. 11. Basic diagram of the dynamic wireless charging system $(94,95)$

In dynamic wireless charging, secondary coil such as static wireless charging is mounted under the vehicle. When electric vehicles pass over the coil placed on the road, a magnetic field is created and an inverter converts AC to DC power and stores the energy in battery groups. With this method, required battery capacity for electric cars is reduced by approximately $20 \%$ (75). In dynamic charging process, the transmitter coil and necessary components must be installed in predetermined locations (96). As shown in Fig. 11 and 12, the coil in the transmitter state can be placed in two different ways. First, a large coil, and next, small coils can be placed (97). Deciding on which method to use depend on the road structure, desired efficiency rate and cost (98). In the dynamic wireless charging model, the initial setup cost is high (99), but the efficiency level will increase while the initial construction cost will decrease with autonomous vehicles in the future. This charging system can be actively used in passenger cars, commercial trucks, and transportation services such as buses and railways. In Table 6 $(100-107)$ the development of the dynamic wireless charging system is summarized.

Table 6. Development of the dynamic wireless charging system (90)

\begin{tabular}{c|c|c}
\hline $\begin{array}{c}\text { Research and Development In- } \\
\text { stitute }\end{array}$ & $\begin{array}{c}\text { Power } \\
(\mathrm{kW})\end{array}$ & Efficiency (\%) \\
\hline Oak Ridge National Labora- & 20 & 90 \\
\hline University of Auckland, New & $20-30$ & 85 \\
\hline Japan Railway Technical Re- & 50 & TBA \\
\hline KAIST University, Korea & $25-100$ & 85 \\
\hline Flanders Drive with industries & 80 & $88-90$ \\
\hline EV System Lab \& Nissan Re- & 1 & $>90$ \\
\hline North Carolina State Univer- & 0.3 & $77-90$ \\
\hline
\end{tabular}

In a dynamic charging system, the energy transferred to the battery depends on several factors (81). The speed of the vehicle and the power of the charging system play an important role in the amount of energy transferred. This system is divided into two ac- cording to the coil structure on the transmitter side; single and segmented transmitters. Each system has its advantages and disadvantages. In a single transmitter system, it is buried as a single transmitter on the road as seen in Fig. 12. The coil placed under the vehicle is smaller. The advantages of such a system are;

1. Only one source is connected to the transmitter and it is named as the main source. Multiple resource costs are eliminated.

2. As the vehicle moves along the road where the system is integrated, the connection coefficient between the coils is almost constant and the movement of the vehicle considerably affects the connection parameters.

The different lengths of the primary and secondary coils also lead to some vital disadvantages. These are;

1. Harmful electromagnetic waves may be emitted.

2. Compensation capacitor to be located on the primary coil should be spread throughout the coil, which requires extra cost.

3. The efficiency of the transferred power will be low.

In the segmented coil structure presented in Fig. 11, the energy of the main source sent to the system is divided into more than one coil. In addition to the main source, there are multiple helpful resources here. The coil or coil group closest to the vehicle is connected to the main source. This way, the magnetic waves propagating outward are minimized. Unlike the other method, a long coil is not active on the road and the coil that the vehicle passes over will be active. The location of the vehicle is crucial in this system. Since the coils will be energized according to the vehicle position, the energization of the first coil is vital for the others. This is the most important disadvantage of the split coil charging method. Another disadvantage is to optimize the distance between the coils on the road. Both dynamic wireless charging methods can be applied in a reliable way, considering the road structure, cost and efficiency (97).

\section{Electric Vehicle Charging Stations in Turkey}

Renault Fluence ZE was the first electric vehicle to be sold in Turkey in 2012. The electric vehicle market diversified with the addition of BMW i3 and Renault Zoe models in 2014. In recent years, fully electric vehicle sales began to gain momentum in the world, despite the preference for more hybrid cars in Turkey's automotive market. Technical specifications of the charging system of the electric vehicles in Turkey are presented in Table 7. In particular, Turkey's efforts to manufacture its own electric vehicle is considered to be a major cause of this increase (108).

In Turkey, 889 electric cars were sold in 2015 and sales were increased $30 \%$ in 2016, and $45 \%$ in 2017. In 2018, sales figures were increased a record high $218 \%$ and later in 2019, the increase was $280 \%$. In 2020, a large increase in sales figures is not expected due to the economic bottleneck and decreasing consumption trend in the world due to the epidemic. As of February 2020, a total of 
17,749 electric vehicles were sold. Another factor in the increase in sales over the years can be shown as the increase in the number of charging stations throughout the country (108). Electric vehicle sales figures from TSE (Turkish Standardization Institute) data presented in Table 8 (109).

Between the years of 2011-2020, total of 1126 charging stations were installed which corresponds to one station per two electric cars. Total of 11 companies invest in the charging infrastructure while 18 companies are involved in sales and marketing (110) . 122 of 582 charging points in Turkey are CHAdeMO and CCS which supports DC fast charging. Other charging stations are AC devices that are designed and manufactured according to the EU standards (110). The map of installed charging stations can be found in Fig. 12.
Table 7. Technical characteristics of the first market of electric vehicles charging system in Turkey

\begin{tabular}{|c|c|c|c|c|}
\hline & $\begin{array}{c}\text { AC Charge } \\
(1 \text { or } 3 \text { phase }) \\
\text { Maximum } \\
\text { Input Power }(\mathrm{kW})\end{array}$ & $\begin{array}{l}\text { Battery } \\
\text { Capacity } \\
\text { (kWh) }\end{array}$ & $\begin{array}{l}\text { Approx. } \\
\text { Range } \\
(\mathrm{km})\end{array}$ & $\begin{array}{c}\text { DC Charge } \\
\text { Option }\end{array}$ \\
\hline Renault Zoe & 1 or $3 / 43$ & $22 / 41$ & $\begin{array}{c}240 / 400 \\
\text { (NEDC) }\end{array}$ & No \\
\hline $\begin{array}{l}\text { Tesla Model } \\
\text { S 75D }\end{array}$ & 1 or $3 / 22$ & 75 & $\begin{array}{c}490 \\
\text { (NEDC) }\end{array}$ & $\begin{array}{c}\text { Yes } \\
\text { (Tesla) }\end{array}$ \\
\hline BMW i3 & 1 or $3 / 11$ & $22 / 33$ & $\begin{array}{l}190 / 300 \\
\text { (NEDC) }\end{array}$ & $\begin{array}{c}\text { Yes } \\
\text { (Combo) }\end{array}$ \\
\hline Nissan Leaf & $1 / 7.4$ & $24 / 30$ & $\begin{array}{c}200 / 250 \\
\text { (NEDC) }\end{array}$ & $\begin{array}{c}\text { Yes } \\
\text { (CHAdeMO) }\end{array}$ \\
\hline $\begin{array}{l}\text { Ford Focus } \\
\text { Electric }\end{array}$ & $1 / 6.6$ & 33.5 & $\begin{array}{c}185 \\
\text { (EPA) }\end{array}$ & Yes (Combo) \\
\hline Chevy Bolt & $1 / 7.4$ & 60 & $\begin{array}{c}383 \\
\text { (EPA) }\end{array}$ & Yes (Combo) \\
\hline $\begin{array}{c}\text { Chevy Volt } \\
\text { PHEV }\end{array}$ & $1 / 3.3$ & 16 & $\begin{array}{c}60 \\
(\mathrm{EPA})\end{array}$ & No \\
\hline
\end{tabular}

Table 8. TUIK, vehicles with internal-combustion engine, February 2020 (109)

\begin{tabular}{cccccccccc}
\hline Year & Total & Gasoline & $(\boldsymbol{\%})$ & Diesel & $\boldsymbol{( \% )}$ & LPG & $\boldsymbol{( \% )}$ & Electric - Hybrid & $(\boldsymbol{\%})$ \\
\hline $\mathbf{2 0 1 1}$ & 8.113 .111 & 3.036 .129 & 37,4 & 1.756 .034 & 21,6 & 3.259 .288 & 40,2 & $\mathbf{4 7}$ & 0,0 \\
$\mathbf{2 0 1 2}$ & 8.648 .875 & 2.929 .216 & 33,9 & 2.101 .206 & 24,3 & 3.569 .143 & 41,3 & $\mathbf{2 2 8}$ & 0,0 \\
$\mathbf{2 0 1 3}$ & 9.283 .923 & 2.888 .610 & 31,1 & 2.497 .209 & 26,9 & 3.852 .336 & 41,5 & $\mathbf{4 3 6}$ & 0,0 \\
$\mathbf{2 0 1 4}$ & 9.857 .915 & 2.855 .078 & 29,0 & 2.882 .885 & 29,2 & .076 .730 & 41,4 & $\mathbf{5 2 5}$ & 0,0 \\
$\mathbf{2 0 1 5}$ & 10.589 .337 & 2.927 .720 & 27,6 & 3.345 .951 & 31,6 & .272 .044 & 40,3 & $\mathbf{8 8 9}$ & 0,0 \\
$\mathbf{2 0 1 6}$ & 11.317 .998 & 3.031 .744 & 26,8 & 3.803 .772 & 33,6 & .439 .631 & 39,2 & $\mathbf{1 . 1 6 0}$ & 0,0 \\
$\mathbf{2 0 1 7}$ & 12.035 .978 & 3.120 .407 & 25,9 & 4.256 .305 & 35,4 & .616 .842 & 38,4 & $\mathbf{1 . 6 8 5}$ & 0,0 \\
$\mathbf{2 0 1 8}$ & 12.398 .190 & 3.089 .626 & 24,9 & 4.568 .665 & 36,8 & .695 .717 & 37,9 & $\mathbf{5 . 3 6 7}$ & 0,0 \\
$\mathbf{2 0 1 9}$ & 12.503 .049 & 3.020 .017 & 24,2 & 4.769 .714 & 38,1 & .661 .707 & 37,3 & $\mathbf{1 5 . 0 5 3}$ & 0,1 \\
$\mathbf{2 0 2 0}$ & 12.598 .885 & 3.041 .995 & 24,1 & 4.813 .165 & 38,2 & .689 .549 & 37,2 & $\mathbf{1 7 . 7 4 9}$ & 0,1 \\
(1) Data as of the end of February. & & & & & & &
\end{tabular}

Analysis based on the country's regions has been conducted on the current charging stations that are actively being used. Based on the results, Marmara region has the most charge type variety and there are 251 charging stations in total. These charging stations house CCS/SAE, CHAdeMO, J-1772 (Type 1), Tesla and Type 2 connectors. The charging stations shown in orange in Fig. 13 are designated as CHAdeMO and CCS. Green stations indicate other AC charging sockets. 


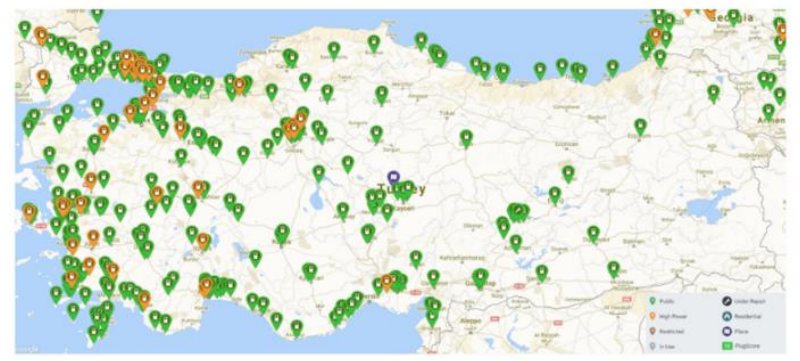

Fig. 12. Charging stations in Turkey

There are total of 86 charging stations in the Mediterranean Region. These charging stations continue to operate with $\mathrm{CCS}$, CHAdeMO, J-1772 (Type 1) and Type 2 sockets. There are 62 charging stations in total in the Aegean Region and the charging socket types are similar to the Mediterranean Region. The charging socket in the eastern part of Turkey provide slowest power charge. There are total of 21 charging stations in the Eastern Anatolia Region and these charging stations have Type 1 and Type 2 charging sockets. Type 2 charging sockets are used effectively in the Southeastern Anatolia Region. CHAdeMO charging sockets are used in 2 charging stations in total. Though there are future plans but there are no Superchargers in Turkey as it is owned and operated by Tesla. High charging power demand is met from CCS and CHAdeMO charging sockets.

Table 9. Type of charging stations in Turkey

\begin{tabular}{|c|c|c|c|c|c|c|c|c|c|}
\hline \multirow[b]{2}{*}{ Region } & \multirow[b]{2}{*}{ 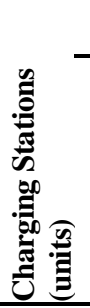 } & \multicolumn{8}{|c|}{ Charging Station Type } \\
\hline & & 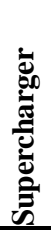 & 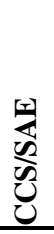 & 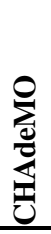 & $\frac{N}{5}$ & 亲 & 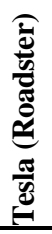 & $\underset{y}{N}$ & r \\
\hline Marmara & 251 & $\mathrm{x}$ & $\checkmark$ & $\checkmark$ & $\checkmark$ & $\checkmark$ & $\mathrm{x}$ & $\checkmark$ & $\mathrm{x}$ \\
\hline Mediterranean & 86 & $\mathrm{x}$ & $\checkmark$ & $\checkmark$ & $\checkmark$ & $\mathrm{x}$ & $\mathrm{x}$ & $\checkmark$ & $\mathrm{x}$ \\
\hline Aegean & 62 & $\mathrm{x}$ & $\checkmark$ & $\checkmark$ & $\checkmark$ & $\mathrm{x}$ & $\mathrm{x}$ & $\checkmark$ & $\mathrm{x}$ \\
\hline $\begin{array}{l}\text { Central } \\
\text { Anatolia }\end{array}$ & 95 & $\mathrm{x}$ & $\checkmark$ & $\checkmark$ & $\checkmark$ & $\mathrm{x}$ & $\mathrm{x}$ & $\checkmark$ & $\mathrm{x}$ \\
\hline Black Sea & 33 & $\mathrm{x}$ & $\mathrm{x}$ & $\mathrm{x}$ & $\checkmark$ & $\mathrm{x}$ & $\mathrm{x}$ & $\checkmark$ & $\mathrm{x}$ \\
\hline $\begin{array}{l}\text { Eastern } \\
\text { Anatolia }\end{array}$ & 21 & $\mathrm{x}$ & $\mathrm{x}$ & $\mathrm{X}$ & $\checkmark$ & $\mathrm{x}$ & $\mathrm{x}$ & $\checkmark$ & $\mathrm{x}$ \\
\hline $\begin{array}{c}\text { Southeastern An- } \\
\text { atolia }\end{array}$ & 34 & $\mathrm{x}$ & $\checkmark$ & $\mathrm{x}$ & $\checkmark$ & $\mathrm{x}$ & $\mathrm{x}$ & $\checkmark$ & $\mathrm{x}$ \\
\hline Total & 582 & & & & & & & & \\
\hline
\end{tabular}

Currently there is no charging station in Turkey that can supply $250 \mathrm{~kW}$ or more power. It is thought that this investment is not made due to the lack of the vehicles supporting high levels of power. The medium-level fast charging need of the electric cars sold was met from the CHAdeMO and CCS charging sockets. The most commonly installed type of charging socket was Type 2. All regions include at least one charging station with Type 2 charging socket. Wireless charging station infrastructure in Turkey is used in general in a shopping mall and underground parking lots. Cable station structure was used for intercity roads. Number of charging stations and socket types in Turkey are presented in Table 9.

\section{Conclusions}

This article provides a review of the wired and wireless charging systems in use that are standardized or candidates for standardization. Wired or wireless charging systems have different features according to environmental conditions, cost and structures of electric vehicles and can be applied in different ways. Wired charging systems are developed according to different power levels and types so that users can choose depending on the desired charging power and cost. For example, AC charging systems are produced and presented as standard in different power values as Level 1, Level 2 and Level 3. In addition, since each country has different electricity, power and connector standards, charging systems are produced with different types of connectors. These are namely; Type 1, Type2, Type 3 and Type 4. There are different types of charging modes regarding the method of application of wired charging. These charging modes are direct connection to the household socket, connection to the socket with mobile charging equipment, connection to the fixed charger with the standard charging cable and connection to the fixed DC charging station with the standard charging cable. It is referred to as Mode 1, Mode 2, Mode 3, and Mode 4, respectively.

Wireless charging is still a new application for electric vehicle technology. If in the future, reducing the battery capacity of electric vehicles is desired, it is predicted that this method can be applied easily, especially in downtowns. With continuous developments in battery technology, the path how wireless charging can be applied has already been determined, and studies on the commercial aspects of charging technologies still continue. The popularity of electric vehicles are growing from day to day and they are rapidly spreading worldwide especially in the industrialized countries. In Turkey, electric vehicles were introduced commercially in 2012. In addition to the increasing user interest, the accessibility of this technology is also noticed by the government and industrial organizations.

It is understood that, unlike the internal combustion engine technology, electric vehicle technology is still viable, applicable and developable in Turkey. This approach can be seen clearly by the work done under the roof of Turkey's Automobile Enterprise Group (TAEG - TOGG), which is supported by both the government and the private sector. Some commercial vehicle manufacturers started working on electric public transport vehicles well ahead of TOGG initiatives (111-114). Apart from these, electric vehicle studies have been carried out within various universities (115-117). With the help of competitions and calls supported by the Scientific and Technological Research Council of Turkey (TÜBITAK), it is seen that the processes to increase infrastructure and human resources competencies for both attracting attention and the development of technology are carried out successfully. In the light of this awareness, the private sector started their infrastructure activities in charging stations, which are essential for 
electric vehicles. It is seen that numerous companies' charging station projects completed their R\&D phase and started the production phase. Some of these companies offer installation and sales services as well as production.

In this study, charging systems of electric vehicles have been reviewed, and how these systems are formed, constructed and operated within the framework of standards is presented. Electric vehicle charging technologies from Turkey's perspective were presented with the latest information and studies observing the installation of charging stations in the country. Charging stations in Turkey were examined according to regions and connector types.

This study reveals that high-power charging station installations are very limited. In addition, there are widely used medium power level charging stations with CCS and CHAdeMO connectors. It has been determined that there are no DC fast charging stations in the eastern and northern regions of the country and mostly Type 2 charging connectors are used. Dynamic wireless charging points and higher power DC charging stations have not been installed, as the demand for high-power charging stations has not yet formed a feasible investment trade-off. Establishment of appropriate infrastructures for this type of charging stations that will affect the existing grid at a minimal level will be considered as a separate subject of study. With the increasing interest in electric cars, it is considered that the installation of such high-speed charging stations will accelerate, and academic studies should be carried out until the market reaches a reasonable volume. This study is aimed to be a resource for researchers who will work on charging stations of electric vehicles.

\section{Conflict of Interest Statement}

The authors declare that there is no conflict of interest in the study.

\section{Credit Author Statement}

Yunus Emre Ekici: Conceptualization, Writing-original draft, İsmail Can Dikmen: Conceptualization, Formal analysis, Mustafa Nurmuhammed: Data curation, Formal analysis, Teoman Karadağ: Conceptualization, Supervision

\section{References}

[1] British Autocars for the Sultan of Turkey. The Autocar. 1895;

[2] An Electric Dog-Cart. Eng. 1888;218.

[3] Rajashekara K. Present status and future trends in electric vehicle propulsion technologies. IEEE J Emerg Sel Top Power Electron. 2013;1(1):3-10.

[4] Wikipedia. EV1 [Internet]. 2020. Available from: https://tr.wikipedia.org/wiki/EV1

[5] Ching Chuen Chan. THE RISE \& FALL OF ELECTRIC. Proc IEEE. 2013;101(1):206-12.

[6] Ekici YE. BATARYA YÖNETIM SİSTEMLERİ. 2019.

[7] International Energy Agency (IEA). Global EV Outlook 2020: Entering the decade of electric drive? Glob EV Outlook 2020. 2020;273.
[8] Global energy \& CO2 status report 2017 [Internet]. Available from: https://scholar.google.com/scholar?cluster $=971223945886245125 \&$ $\mathrm{hl}=\mathrm{tr} \&$ as_sdt=2005\&sciodt $=0,5$

[9] He T, Bai Y, Zhu J. Optimal charging strategy of electric vehicles customers in a smart electrical car park. IET Conf Publ. 2016;2016(CP684):3-8.

[10] Yilmaz U, Turksoy O, Teke A. Intelligent control of high energy efficient two-stage battery charger topology for electric vehicles. Energy [Internet]. 2019;186:115825. Available from: https://doi.org/10.1016/j.energy.2019.07.155

[11] Ruiz V, Pfrang A, Kriston A, Omar N, Van den Bossche P, BoonBrett L. A review of international abuse testing standards and regulations for lithium ion batteries in electric and hybrid electric vehicles. Renew Sustain Energy Rev [Internet]. 2018;81(April):1427-52. Available from: http://dx.doi.org/10.1016/j.rser.2017.05.195

[12] Emadi A, Rajashekara K, Williamson SS, Lukic SM. Topological overview of hybrid electric and fuel cell vehicular power system architectures and configurations. IEEE Trans Veh Technol. 2005;54(3):763-70.

[13] Hoque MM, Hannan MA, Mohamed A, Ayob A. Battery charge equalization controller in electric vehicle applications: A review. Renew Sustain Energy Rev [Internet]. 2017;75(November):1363-85. Available from: http://dx.doi.org/10.1016/j.rser.2016.11.126

[14] DERİCIOĞLU Ç, YİRIK E, ÜNAL E, CUMA MU, ONUR B, TÜMAY M. a Review of Charging Technologies for Commercial Electric Vehicles. Int J Adv Automot Technol. 2018;(June 2019).

[15] Praneeth AVJS, Williamson SS. A Review of Front End AC-DC Topologies in Universal Battery Charger for Electric Transportation. 2018 IEEE Transp Electrif Conf Expo, ITEC 2018. 2018;916-21.

[16] I. Wagner. Worldwide number of battery electric vehicles in use from 2012 to 2018 [Internet]. Available from: https://www.statista.com/statistics/270603/worldwide-number-ofhybrid-and-electric-vehicles-since-2009/

[17] A YOUNG. Global Electric Car Market: About 43\% Of All Electric Passenger Cars Were Bought In 2014, Say German Clean Energy Researchers [Internet]. Available from: https://scholar.google.com/scholar_lookup?title=Global Electric Car Market\%3A about $43 \% 25$ of all electric passenger cars were bought in 2014\&author=A. Young\&publication_year=2015

[18] insideevs. FINAL UPDATE: Quarterly Plug-In EV Sales Scorecard [Internet]. Available from: https://insideevs.com/news/343998/monthly-plug-in-ev-salesscorecard/

[19] Zheng Z, Liu T, Zhang Y, Cheng X. Analysis on development trend of electric vehicle charging mode. ICEOE 2011 - 2011 Int Conf Electron Optoelectron Proc. 2011;1(Iceoe):440-2.

[20] Gao Y, Zhang X, Cheng Q, Guo B, Yang J. Classification and Review of the Charging Strategies for Commercial Lithium-Ion Batteries. IEEE Access. 2019;7:43511-24.

[21] He J, Yang H, Huang HJ, Tang TQ. Impacts of wireless charging lanes on travel time and energy consumption in a two-lane road system. Phys A Stat Mech its Appl [Internet]. 2018;500:1-10. Available from: https://doi.org/10.1016/j.physa.2018.02.074

[22] Pappas JCK. a New Prescription for Electric Cars. Energy Law J 
[Internet]. 2014;35(1):151-98. Available from: http://search.ebscohost.com/login.aspx?direct=true \&db=bth\&AN=9 6365764\&site $=$ ehost-live

[23] Bräunl T. EV Charging Standards. 2012;1-5. Available from: http://therevproject.com/doc/2012-EVcharging-s.pdf

[24] Bohn T. Vehicle Charging; Low Level AC To DC Extreme Fast Charging For Commercial Vehicles. 2019;1-6.

[25] SAE Electric Vehicle and Plug in Hybrid Electric Vehicle Conductive Charge Coupler J1772_201001. 2010.

[26] Channegowda J, Pathipati VK, Williamson SS. Comprehensive review and comparison of DC fast charging converter topologies: Improving electric vehicle plug-to-wheels efficiency. IEEE Int Symp Ind Electron. 2015;2015-Septe:263-8.

[27] Wikipedia. SAE J1772 [Internet]. 2020. Available from: https://en.wikipedia.org/wiki/SAE_J1772

[28] SAE. J1772_201001 [Internet]. SAE Electric Vehicle and Plug in Hybrid Electric Vehicle Conductive Charge Coupler. 2010. Available

from: https://www.sae.org/standards/content/j1772_201001/

[29] Yilmaz M, Krein PT. Review of battery charger topologies, charging power levels, and infrastructure for plug-in electric and hybrid vehicles. IEEE Trans Power Electron. 2013;28(5):2151-69.

[30] Karlsson P, Svensson J. DC Bus Voltage Control for a Distributed Power System. IEEE Trans Power Electron. 2003;18(6):1405-12.

[31] SAE. Charging - what can be more simple? [Internet]. Available from:

https://www.sae.org/binaries/content/assets/cm/content/standards/ch argingprimer.pdf

[32] TE Connectivity. SAE J1772 Electric Vehicle Charge Connector Cable Assembly. 2015.

[33] McPhail D. Evaluation of ground energy storage assisted electric vehicle DC fast charger for demand charge reduction and providing demand response. Renew Energy [Internet]. 2014;67:103-8. Available from: http://dx.doi.org/10.1016/j.renene.2013.11.023

[34] America EN, Phoenix A. Lessons Learned - The EV Project DC Fast Charge - Demand Charge Reduction Prepared for the U . S . Department of Energy Award \# DE-EE0002194. 2012.

[35] Ashique RH, Salam Z, Bin Abdul Aziz MJ, Bhatti AR. Integrated photovoltaic-grid dc fast charging system for electric vehicle: A review of the architecture and control. Renew Sustain Energy Rev [Internet]. 2017;69(October 2016):1243-57. Available from: http://dx.doi.org/10.1016/j.rser.2016.11.245

[36] Harighi T, Bayindir R, Padmanaban S, Mihet-Popa L, Hossain E. An overview of energy scenarios, storage systems and the infrastructure for Vehicle-to-Grid technology. Energies. 2018;11(8):1-18.

[37] Ahmad A, Alam MS, Chabaan R. A Comprehensive Review of Wireless Charging Technologies for Electric Vehicles. IEEE Trans Transp Electrif. 2017;4(1):38-63.

[38] Harighi T, Bayindir R. Load Estimation Use in Electric Vehicle Charge Station Coordination in Different Node and Definite Area. 6th IEEE Int Conf Smart Grid, icSmartGrids 2018. 2019;264-71.

[39] Mwasilu F, Justo JJ, Kim EK, Do TD, Jung JW. Electric vehicles and smart grid interaction: A review on vehicle to grid and renewable energy sources integration. Renew Sustain Energy Rev [Internet].
2014;34:501-16.

Available

http://dx.doi.org/10.1016/j.rser.2014.03.031

[40] Liu L, Kong F, Liu X, Peng Y, Wang Q. A review on electric vehicles interacting with renewable energy in smart grid. Renew Sustain Energy Rev [Internet]. 2015;51:648-61. Available from: http://dx.doi.org/10.1016/j.rser.2015.06.036

[41] Berman B. CHAdeMO and China release new EV quick-charging standard, in a bid to leapfrog the industry. 2020.

[42] Wallboxok. CHARGE MODES AND TYPES IN THE ELECTRIC CAR MARKET [Internet]. 2017. Available from: https://www.v2charge.com/modes-and-types-of-recharge-in-theelectric-car-market/

[43] dekra. Electric Vehicle conductive charging system. 2013;1-73.

[44] 61851 I. International Standard International Standard. 61010-1 C) Iec2001. 2006;2006:13.

[45] Ricaud C, Vollet P. Connection method for charging systems - a key element for electric vehicles. Schneider Electr [Internet]. 2010; Available from: http://www.schneiderelectric.co.uk/documents/electrical-

distribution/en/local/ev/Connection-method-for-charging-

systems.pdf

[46] EN IEC 61851-1. Electric vehicle conductive charging system [Internet]. Available from: https://standards.globalspec.com/std/13385383/en-iec-61851-1

[47] Wu YE. Design and implementation of AC conductive charging system for electrical vehicles. 2019 2nd Int Conf Electron Technol ICET 2019. 2019;282-8.

[48] Pod Point. EV Charging Connectors [Internet]. Available from: https://pod-point.com/guides/driver/ev-connector-types-speed

[49] Güneş D, Tekdemir İG, Karaarslan MŞ, Alboyacı B. Assessment of the impact of electric vehicle charge station loads on reliability indices. J Fac Eng Archit Gazi Univ. 2018;33(3):1073-84.

[50] ENEL X. The Different EV Charging Connector Types [Internet]. Available from: https://evcharging.enelx.com/eu/about/news/blog/552-ev-chargingconnector-types

[51] SAE. SAE Electric Vehicle and Plug in Hybrid Electric Vehicle Conductive Charge Coupler [Internet]. Available from: https://www.sae.org/standards/content/j1772_201710/

[52] Schmutzler J, Andersen CA, Wietfeld C. Evaluation of OCPP and IEC 61850 for smart charging electric vehicles. World Electr Veh J. 2013;6(4):863-74.

[53] NZTA. Charging point connectors and socket outlets [Internet]. Available from: https://www.nzta.govt.nz/planning-andinvestment/planning/transport-planning/planning-for-electricvehicles/national-guidance-for-public-electric-vehicle-charginginfrastructure/charging-point-connectors-and-socket-outlets/

[54] Wikipedia. Tesla Supercharger [Internet]. Available from: https://en.wikipedia.org/wiki/Tesla_Supercharger

[55] Mennek. Type 2 charging plug proposed as the common standard for Europe [Internet]. Available from: http://www.mennek.es/index.php?id=latest0\&L=2\&tx_ttnews[tt_ne ws $]=929 \& \mathrm{cHash}=46 \mathrm{a} 00 \mathrm{bad} 7 \mathrm{f0d} 569 \mathrm{c} 00 \mathrm{bea} 9537556 \mathrm{bbeb}$

[56] Carlson WB. Inventor of Dreams [Internet]. Available from: https://www.scientificamerican.com/article/inventor-of-dreams/ 
[57] Chatterjee S, Iyer A, Bharatiraja C, Vaghasia I, Rajesh V. Design Optimisation for an Efficient Wireless Power Transfer System for Electric Vehicles. Energy Procedia [Internet]. 2017;117:1015-23. Available from: http://dx.doi.org/10.1016/j.egypro.2017.05.223

[58] Sun L, Ma D, Tang H. A review of recent trends in wireless power transfer technology and its applications in electric vehicle wireless charging. Renew Sustain Energy Rev [Internet]. 2018;91(March):490-503. Available from: https://doi.org/10.1016/j.rser.2018.04.016

[59] Bi Z, Kan T, Mi CC, Zhang Y, Zhao Z, Keoleian GA. A review of wireless power transfer for electric vehicles: Prospects to enhance sustainable mobility. Appl Energy [Internet]. 2016;179:413-25. Available from: http://dx.doi.org/10.1016/j.apenergy.2016.07.003

[60] Ho JS, Poon ASY. Energy transfer for implantable electronics in the electromagnetic midfield. Prog Electromagn Res. 2014;148(August):151-8.

[61] Brown WC. The History of Power Transmission by Radio Waves. IEEE Trans Microw Theory Tech. 1984;32(9):1230-42.

[62] Glasser PE. Power from the sun: Its future. 1968. p. 857-61.

[63] Kurs A, Karalis A, Moffatt R, Joannopoulos JD, Fisher P, Soljačić M. Wireless power transfer via strongly coupled magnetic resonances. Science (80- ). 2007;317(5834):83-6.

[64] Zhang Y, Zhao Z, Chen K. Frequency decrease analysis of resonant wireless power transfer. IEEE Trans Power Electron. 2014;29(3):1058-63.

[65] Zhang Y, Zhao Z, Chen K. Frequency-splitting analysis of four-coil resonant wireless power transfer. IEEE Trans Ind Appl. 2014;50(4):2436-45.

[66] Park KJ, Lim J, Kim KY. The effect of the relationships between affiliated firms on direction of income shifting within business groups. J Appl Bus Res. 2014;30(3):817-32.

[67] Choi BH, Lee ES, Huh J, Rim CT. Lumped Impedance Transformers for Compact and Robust Coupled Magnetic Resonance Systems. IEEE Trans Power Electron. 2015;30(11):6046-56.

[68] Miller JM, Onar OC, Chinthavali M. Primary-side power flow control of wireless power transfer for electric vehicle charging. IEEE J Emerg Sel Top Power Electron. 2015;3(1):147-62.

[69] Mi CC, Buja G, Choi SY, Rim CT. Modern Advances in Wireless Power Transfer Systems for Roadway Powered Electric Vehicles. IEEE Trans Ind Electron. 2016;63(10):6533-45.

[70] Li S, Mi CC. Wireless power transfer for electric vehicle applications. IEEE J Emerg Sel Top Power Electron. 2015;3(1):4-17.

[71] Machura P, Li Q. A critical review on wireless charging for electric vehicles. Renew Sustain Energy Rev [Internet]. 2019;104(January):209-34. Available from: https://doi.org/10.1016/j.rser.2019.01.027

[72] EPA. Greenhouse Gas Emissions [Internet]. Available from: https://www.epa.gov/ghgemissions/inventory-us-greenhouse-gasemissions-and-sinks-1990-2005

[73] Rahman I, Vasant PM, Singh BSM, Abdullah-Al-Wadud M, Adnan $\mathrm{N}$. Review of recent trends in optimization techniques for plug-in hybrid, and electric vehicle charging infrastructures. Renew Sustain Energy Rev [Internet]. 2016;58:1039-47. Available from: http://dx.doi.org/10.1016/j.rser.2015.12.353

[74] Li L, Wang Z, Gao F, Wang S, Deng J. A family of compensation topologies for capacitive power transfer converters for wireless electric vehicle charger. Appl Energy [Internet]. 2020;260(5):114156. Available from: https://doi.org/10.1016/j.apenergy.2019.114156

[75] Jang YJ. Survey of the operation and system study on wireless charging electric vehicle systems. Transp Res Part C Emerg Technol [Internet]. 2018;95(November 2017):844-66. Available from: https://doi.org/10.1016/j.trc.2018.04.006

[76] Choi SY, Gu BW, Jeong SY, Rim CT. Advances in wireless power transfer systems for roadway-powered electric vehicles. IEEE J Emerg Sel Top Power Electron. 2015;3(1):18-36.

[77] Kalwar KA, Aamir M, Mekhilef S. A design method for developing a high misalignment tolerant wireless charging system for electric vehicles. Meas J Int Meas Confed [Internet]. 2018;118:237-45. Available

from: http://dx.doi.org/10.1016/j.measurement.2017.12.013

[78] Ko YD, Jang YJ. Efficient design of an operation profile for wireless charging electric tram systems. Comput Ind Eng. 2019;127(xxxx):1193-202.

[79] Cho DH, Jung GH, Yoon U, Lee B. Development \& Implementation of Electric Tram System with Wireless Charging Technology. ICT Express [Internet]. 2015;1(1):34-8. Available from: http://dx.doi.org/10.1016/S2405-9595(15)30019-9

[80] Bombardier. Bombardier PRIMOVE team. Projects of Bombardier PRIMOVE [Internet]. Available from: https://rail.bombardier.com/en.html

[81] Onar OC, Miller JM, Campbell SL, Coomer C, White CP, Seiber LE. A novel wireless power transfer for in-motion EV/PHEV charging. Conf Proc - IEEE Appl Power Electron Conf Expo - APEC. 2013;3073-80.

[82] Mark Kane. China's ZTE Working On 30 kW Wireless Charging [Internet]. Available from: https://insideevs.com/news/327537/chinas-zte-working-on-30-kwwireless-charging/

[83] Marsyukov V, Zhuldassov N, Bagheri M, Lu M, Naderi MS, Abedinia O, et al. Simulation of Dynamic Inductive Wireless Charging Using Overhead Line. India Int Conf Power Electron IICPE. 2018;2018-Decem:1-6.

[84] Niu S, Xu H, Sun Z, Shao ZY, Jian L. The state-of-the-arts of wireless electric vehicle charging via magnetic resonance: principles, standards and core technologies. Renew Sustain Energy Rev [Internet]. 2019;114(June):109302. Available from: https://doi.org/10.1016/j.rser.2019.109302

[85] Afridi K. Wireless charging of electric vehicles [Internet]. 4th ed. Vol. 47, Bridge. Elsevier Inc.; 2017. 17-22 p. Available from: http://dx.doi.org/10.1016/B978-0-12-811407-0.00038-6

[86] Klontz KW, Esser A, Bacon RR, Divan DM, Novotny DW, Lorenz RD. An electric vehicle charging system with "universal" inductive interface. Proc Power Convers Conf - Yokohama 1993. 1993;22732.

[87] Kalwar KA, Aamir M, Mekhilef S. Inductively coupled power transfer (ICPT) for electric vehicle charging - A review. Renew Sustain Energy Rev [Internet]. 2015;47:462-75. Available from: http://dx.doi.org/10.1016/j.rser.2015.03.040

[88] Choi Y, Kwak B, Kim M. 4kW magnetic resonance Wireless Power System. 2016;7-9. 
[89] Sandrine S, JOHN P. Greening the Accounts. Power Syst [Internet]. 2012;19(11):2-4. Available from: http://www.springerlink.com/index/10.1007/978-1-4614-01346\%5Cnhttp://dx.doi.org/10.1016/j.renene.2013.11.019\%5Cnhttp://d x.doi.org/10.1016/j.rser.2012.09.028\%5Cnhttp://www.scopus.com/i nward/record.url?eid=2-s2.084921647184\&partnerID=tZOtx3y1\%5Cnhttp://ww

[90] Panchal C, Stegen S, Lu J. Review of static and dynamic wireless electric vehicle charging system. Eng Sci Technol an Int J [Internet]. 2018;21(5):922-37. Available from: https://doi.org/10.1016/j.jestch.2018.06.015

[91]pluglesspower. Plugless Power [Internet]. 2017. Available from: https://www.pluglesspower.com/shop/

[92]Ahmed K, Aamir M, Uddin MK, Mekhilef S. Misalignment Tolerance of Wireless Charging System. 2015;215-9.

[93]Kuzey S, Balci S, Altin N. Design and analysis of a wireless power transfer system with alignment errors for electrical vehicle applications. Int J Hydrogen Energy [Internet]. 2017;42(28):17928$39 . \quad$ Available from: http://dx.doi.org/10.1016/j.ijhydene.2017.03.160

[94]Panchal C, Stegen S, Lu J. Review of static and dynamic wireless electric vehicle charging system. Eng Sci Technol an Int J. 2018;21(5):922-37.

[95]Wang S, Dorrell D. Review of wireless charging coupler for electric vehicles. IECON Proc (Industrial Electron Conf. 2013;7274-9.

[96]Jang YJ, Ko YD, Jeong S. Optimal design of the wireless charging electric vehicle. 2012 IEEE Int Electr Veh Conf IEVC 2012. 2012;

[97]García-Vázquez CA, Llorens-Iborra F, Fernández-Ramírez LM, Sánchez-Sainz H, Jurado F. Comparative study of dynamic wireless charging of electric vehicles in motorway, highway and urban stretches. Energy. 2017;137:42-57.

[98]Coca E. Wireless Power Transfer: Fundamentals and Technologies [Internet]. 2016. Available from: https://books.google.com.tr/books?hl=tr\&lr=\&id=dGQDwAAQBAJ\&oi=fnd\&pg=PR9\&ots=c6q6oAgBlc\&sig=D22407 axU1IGruXGby5cT71t7Bs\&redir_esc $=\mathrm{y} \# \mathrm{v}=$ onepage $\& \mathrm{q} \& \mathrm{f}=$ false

[99]Liu X, Bie Z. Optimal Allocation Planning for Public EV Charging Station Considering AC and DC Integrated Chargers. Energy Procedia [Internet]. 2019;159:382-7. Available from: https://doi.org/10.1016/j.egypro.2018.12.072

[100] Van Der Pijl F, Bauer P, Castilla M. Control method for wireless inductive energy transfer systems with relatively large air gap. IEEE Trans Ind Electron. 2013;60(1):382-90.

[101] Fuller M. Wireless charging in California: Range, recharge, and vehicle electrification. Transp Res Part C Emerg Technol [Internet]. 2016;67:343-56. Available from: http://dx.doi.org/10.1016/j.trc.2016.02.013

[102] Lee K, Pantic Z, Lukic SM. Reflexive field containment in dynamic inductive power transfer systems. IEEE Trans Power Electron. 2014;29(9):4592-602.

[103] Hata K, Imura T, Hori Y. Dynamic wireless power transfer system for electric vehicles to simplify ground facilities - Sensorless vehicle detection and power control strategy -. EVS 2017 - 30th Int Electr Veh Symp Exhib. 2017;1731-6.

[104] Zhang X, Yuan Z, Yang Q, Li Y, Zhu J, Li Y. Coil Design and
Efficiency Analysis for Dynamic Wireless Charging System for Electric Vehicles. IEEE Trans Magn. 2016;52(7):1-5.

[105] COBB J. Momentum Dynamics' Wireless Charging Could Relegate Plugs To History [Internet]. 2014. Available from: https://www.hybridcars.com/momentum-dynamics-wirelesscharging-could-relegate-plugs-to-history/

[106] Yilmaz M, Krein PT. Review of the impact of vehicle-to-grid technologies on distribution s[1] M. Yilmaz and P. T. Krein, "Review of the impact of vehicle-to-grid technologies on distribution systems and utility interfaces," IEEE Trans. Power Electron., vol. 28, no. 12, pp. 5. IEEE Trans Power Electron. 2013;28(12):5673-89.

[107] Li S, Mi CC. Wireless power transfer for electric vehicle applications. IEEE J Emerg Sel Top Power Electron. 2015;3(1):4-17.

[108] tehad. Elektrikli ve Hibrid Otomobil satışları \%79 arttı [Internet]. Available from: http://tehad.org/2020/04/12/elektrikli-ve-hibridotomobil-satislari-y-artti/

[109] tüik. Motorlu Kara Taşıtları, Şubat 2020 [Internet]. Available from: http://www.tuik.gov.tr/PreHaberBultenleri.do?id=33650

[110] tehad. Türkiye'deki Şarj İstasyonu sayısı Elektrikli Otomobili yakaladi. [Internet]. Available from: http://tehad.org/2019/03/25/turkiyedeki-sarj-istasyonu-sayisielektrikli-otomobili-yakaladi/

[111] Otokar. DORUK ELECTRA [Internet]. Available from: https://commercial.otokar.com.tr/otobus/sehir-ici-otobus/dorukelectra-otobus

[112] Temsa. md9 Electricity [Internet]. Available from: https://www.temsa.com/tr/tr/sehir-ici/md9-electricity

[113] Temsa. avenue electron [Internet]. Available from: https://www.temsa.com/tr/tr/sehir-ici/avenue-electron

[114] Bozankaya. Bozankaya Elektrikli Otobüs [Internet]. Available from: http://www.bozankaya.com.tr/elektrikliotobus/

[115] Dokuz Eylül Ü. SOLARİS EKİBİ, YENİ BAŞARISI “DEMOBİL "İ KUTLUYOR [Internet]. 2015. Available from: http://basin.deu.edu.tr/solaris-ekibi-yeni-basarisi-demobil-ikutluyor/

[116] EVtmotor. TÜRKIYE’NIN YERLİ ELEKTRIKLII OTOMOBİLI [Internet]. Available from: http://www.evtmotor.com.tr/

[117] sabu. REVOLT 9'UNCU OLDU [Internet]. Available from: https://haber.subu.edu.tr/tr/node/249 